\title{
Life history of Karualona muelleri (Richard, 1897) (Chydoridae, Aloninae)
}

\author{
Eliana A. PANARELLI ${ }^{1 *}$ Helen A. O. KAWAMURA ${ }^{1}$, Lourdes M.A. ELMOOR-LOUREIRO ${ }^{2}$, Francisco D.R. SOUSA ${ }^{2,3}$, \\ Paulo H.C. CORGOSINHO ${ }^{4}$, Daniel PREVIATTELLI ${ }^{5}$, Carlos E.F. ROCHA ${ }^{5}$
}

${ }^{1}$ Universidade do Estado de Minas Gerais, Frutal, Rua Mário Palmério 1001, 38200-000 Frutal, MG; ${ }^{2}$ Grupo de Estudos de Ecossistemas Aquáticos - GEEA; ${ }^{3}$ Unidade Acadêmica Especial de Ciências Biológicas, Universidade Federal de Jataí, BR 364 km 195 n 3800 , 75801615, Jataí, GO; ${ }^{4}$ Department of General Biology, UNIMONTES, Campus Universitário Professor Darcy Ribeiro, $39401-089$ Montes Claros, MG; ${ }^{5}$ Instituto de Biociências, Universidade de São Paulo, Rua do Matão n ${ }^{\circ}$ 321, Cidade Universitária, 05508-090 São Paulo, SP, Brazil

\begin{abstract}
Many taxonomic issues still need to be solved for the family Chydoridae, but mainly in the subfamily Aloninae. The species Karualona muelleri is an example of a recent taxonomic redefinition, since it was decoupled from the genus Alona and translocated to another genus. In order to expand our knowledge on the species, we investigated population growth and compared the morphometry of the first and second instars, male, parthenogenetic female, ephippial female, and ephippium. An experimental population was obtained by hatching resting eggs collected from the sediment in a temporary lake located in the Serra da Canastra National Park (Minas Gerais, Brazil). The hatched individuals were subjected to morphometric analyses and used in experiments to assess population growth and fecundity. Reproductive age and lifespan were also monitored in two groups of females in different life stages: parthenogenetic and gamogenetic. The reproductive age occurred between the $1^{\text {st }}$ and $15^{\text {th }}$ days of life, and the greatest longevity was 17 days. The start of gamogenetic reproduction was stimulated by elevated population densities and it characterized the slowdown of exponential population growth. Morphometric analyses detected differences between the development phases, as well as similarities in the morphological features of the male, first and second instars, and the two types of females.
\end{abstract}

\section{INTRODUCTION}

The family Chydoridae has high taxonomic richness compared with the other Cladocera families, but our knowledge of the life histories of the species in this family is still scarce (Martínez-Jerónimo and Gómez-Díaz, 2011; Viti et al., 2013, Silva et al., 2014; Smirnov, 2017), and relatively little is known about the sexual reproduction dynamics of these organisms (Nevalainen and Luoto, 2013).

According to Van Damme et al. (2010), our understanding of the taxonomy of Aloninae has advanced significantly in the last two decades, which is necessary for addressing the taxonomic questions related to the Chydoridae, but also for elucidating the biological

Corresponding author: panarelli1969@gmail.com

Key words: Cladocera; morphometric characteristic; population dynamics; sexual and asexual reproduction.

Edited by: Federico Marrone, University of Palermo, Italy

Received: 25 July 2018

Accepted: 12 July 2019

This work is licensed under a Creative Commons Attribution NonCommercial 4.0 License (CC BY-NC 4.0).

${ }^{\circ}$ Copyright: the Author(s), 2019

Licensee PAGEPress, Italy

J. Limnol., 2019; 78(3): 323-335

DOI: 10.4081/jlimnol.2019.1848 peculiarities of its member species. Karualona muelleri (Richard, 1897) is an example of a recent taxonomic redefinition in the genus Karualona, where Dumont and Silva-Briano (2000) decoupled the species from the polyphyletic taxon Alona Baird, 1843 and allocated it to the karua-group that previously belonged to Biapertura Smirnov 1971. Alona muelleri Richard, 1987 was translocated to the genus Karualona by Sinev and Hollwedel (2005), who also characterized the male based on drawings by Sars (1901) of K. muelleri. Subsequently, Van Damme and Dumont (2010) registered the presence of the male in cultivated samples of sediments from lagoons in Lençóis Maranhenses (northeast Brazil).

According to the studies mentioned above, we know that $K$. muelleri is widely distributed in South America. In Brazil, this species has been registered in the main hydrographic regions of the country (http://cladocera. wordpress.com/) at different altitudes ranging from sea level on the coast at Maranhão (Van Damme and Dumont, 2010) to an altitude of more than $1300 \mathrm{~m}$ in rock fields (this study).

In addition to its taxonomic characteristics and distribution in different ecosystems, it is important to understand the development peculiarities and ecological adaptations of this species. Kotov et al. (2013) considered that neoteny is a significant characteristic of chydorid evolution, where the developmental time is altered relative to other cladocerans and sexual maturity is also reached relatively faster. The small size and low number of juvenile instars, as well as the initiation of reproduction at an early age may comprise a strategy to minimize the 
impacts of predation and shortage of food availability according to Lynch (1980a), whereas sexual reproduction and the production of resting eggs may be considered preparation to tolerate extreme conditions (Fryer, 1996a).

In the present study, we investigated the life history of $K$. muelleri, including estimating its lifespan and population growth, as comparing the morphometric characteristics of the first instar, second instar, parthenogenetic female, ephippial female, male, and parthenogenetic and resting eggs.

\section{METHODS}

\section{Sampling environment}

Specimens were collected from a temporary lake located in a rock field landscape between the watersheds of the Grande and São Francisco rivers, Serra da Canastra National Park (Fig. 1), Minas Gerais (Brazil)

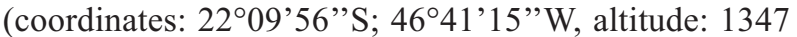
$\mathrm{m})$, in a region with seasonality marked by dry winters and rainy summers. According to Vasconcelos (2011), these rock fields occur mainly above $900 \mathrm{~m}$ and they are mostly associated with quartzite outcrops, sandstone, and mineral iron. In the rock field landscape, the daily temperature variations may exceed the seasonal variations, where the differences are more pronounced in the dry period, with a monthly average ranging between $10^{\circ} \mathrm{C}$ and $16^{\circ} \mathrm{C}$ (Gianotti et al., 2013).

Aquatic organisms in the temporary environments in rock fields are vulnerable to the temporary disappearance of the water body, but also to the occurrence of natural and anthropic fires, which spread rapidly through the typical grasses in the field vegetation. During the dry season, the sampling environment is clearly visible in the landscape because it is surrounded by grasses and the bottom comprises cracked mud covered by dead macrophytes.

The sediment was sampled between July 25 and 27 , 2011, at six sites distributed randomly throughout the dry lake area, before combining into a single sample with a total volume of approximately $750 \mathrm{~cm}^{3}$. At each site, a circular area of $78.54 \mathrm{~cm}^{2}$ was delimited where the
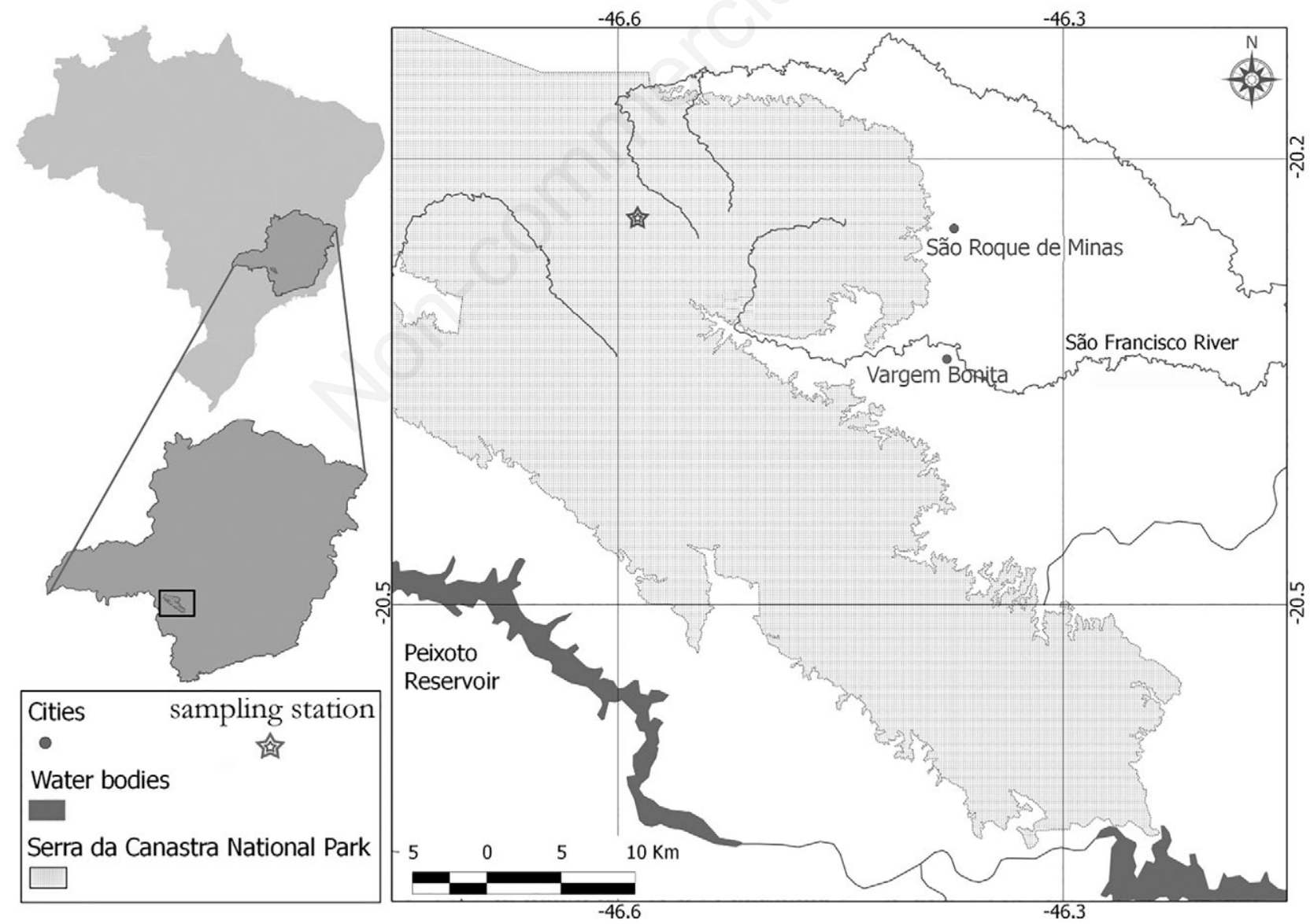

Fig. 1. Location of the sampling site in Serra da Canastra National Park (Minas Gerais, Brazil). 
sediment was obtained with a spoon at a depth of $1 \mathrm{~cm}$ to $2 \mathrm{~cm}$. In the rainy season (March 2012), the individuals in the active phase were collected with plankton nets (45$\mu \mathrm{m}$ mesh) through horizontal hauls.

\section{Characterization of the resting egg hatching and organism cultivation}

On August 27, 2012, the lake sediment was homogenized in the laboratory. Subsamples measuring approximately $50 \mathrm{~mL}$ were conditioned in glass flasks and hydrated at a proportion of $1 / 3$ sediment to $2 / 3$ distilled water according to the Sars' method described by Van Damme and Dumont (2010). The experiment was performed under laboratory conditions at temperatures ranging between $23^{\circ} \mathrm{C}$ and $32^{\circ} \mathrm{C}$ (average: $27^{\circ} \mathrm{C}$ ) and with a photoperiod close to $12 \mathrm{~h}$ light/ $12 \mathrm{~h}$ dark. Hatching was monitored twice each day with a stereomicroscope (magnification up to 50 times).

The occurrence of the active phase was followed by the separation of six females in plastic cups $(50 \mathrm{~mL})$ containing culture medium, which were obtained by filtering $(20-\mu \mathrm{m}$ mesh) distilled water blended with sediment from the lake at the same proportion described above. The increase in the population size was verified daily for 40 days, whereas the culture medium was replaced each week. Moreover, 88 first instar females with similar morphological characteristics were separated (52 were obtained from hatched resting eggs and 36 from parthenogenetic brood) to measure the lifespan, reproductive age, number of eggs, and gaps between reproduction.

After concluding the experiments, the specimens were fixed (in formalin at $4 \%$ ) to obtain morphometric measurements using an optical microscope at magnifications of 100,200 , and 400 times. Two juvenile female instars were identified, as described in several previous studies of Aloninae species with smaller sizes (Frey, 1987; Kotov; 1997; Sinev, 2001; Sinev et al., 2009; Sinev and Elmoor-Loureiro, 2010), but it is possible that the second instar represents instar II+III (see the Discussion). The specimens were divided into three stages in order to obtain the morphometric measurements: first instar, second instar, and adult, where the adults were subdivided into males, parthenogenetic females, and ephippial females, and 57 individuals were studied morphometrically in total. The following characteristics were measured: body length, posterior margin height and maximum height of the carapace, antennule length and width, labrum plate height, distance between eye and ocellus, post-abdomen width, basal claw base width, and length of the claw and its basal spine. The numbers of setules on the carapace ventral margin, spines on the posteroventral angle of the carapace, and post-abdomen marginal teeth were also evaluated.

\section{Analyses of morphometric and population features}

The instantaneous birth rate $(b)$ was estimated according to Paloheimo (1974). The intrinsic rate of population growth $(r)$ and the instantaneous death rate $(d)$ were estimated according to the equation proposed by Edmondson (1971). Exponential growth was considered exclusively for the asexual reproduction period given the following assumptions proposed by Gotteli (2008): i) noninterference in population migration, ii) beginning of reproduction soon after the first day of life, iii) parthenogenetic egg production, and iv) no difference in the reproductive rate relative to the age of the female. The end of exponential growth was characterized by the appearance of sexual reproduction. For the two populations without sexual reproduction, the highest population density observed was considered as the end of the exponential phase.

The morphometric differences were compared by multivariate canonical variable analysis (MANOVA-CV) after data transformation $\left(\log _{10} \mathrm{X}+1\right)$ to satisfy the assumptions of normality and homoscedasticity. PAST software (Hammer et al., 2001) was used to verify whether the set of morphometric variables could discriminate the different life phases, including males and females. The set of morphometric variables used to test the differences among life phases, females (parthenogenetic and gamogenetic), and males comprised: distance between eye and ocellus, labrum plate height, and length of the basal claw on the post-abdomen. The relationships between coupled measurements were also used: height/maximum body length, distal region carapace height/maximum body length, width/length of the antennule, width/length of the post-abdomen, and length of the basal spine/width of the post-abdominal claw base.

\section{RESULTS}

Many of our samples originated from resting egg populations in a dry environment. However, $K$. muelleri was also recorded in an aquatic system where the limnological characteristics during sampling were as follows: depth: $0.5 \mathrm{~m}$; temperature of water column: $22^{\circ} \mathrm{C}$; $\mathrm{pH} 4.76$ to 6.48 ; diluted oxygen: $3.98 \mathrm{mg} \mathrm{L}^{-1}$; and conductivity: $283 \mu \mathrm{S} \mathrm{cm}^{-1}$. The following species were also found at the same site: Alona iheringula Sars, 1901; Alona ossiani Sinev,1998; Flavalona asymmetrica Sousa and Elmoor-Loureiro, 2018; Alonella clathratula Sars, 1986 Celsinotum candango Sinev and Elmoor-Loureiro, 2010; Ephemeroporus barroisi (Richard, 1984); Ephemeroporus tridentatus (Bergamin, 1931); Streblocerus pygmaeus Sars, 1901; and Ilyocryptus spinifer Herrick, 1882.

\section{Morphometric characteristics}

The ephippial female and resting egg are shown in 
Fig. 2, and the morphometric characteristics of every phase are presented in Tab. 1. The peculiar morphological features of the genus Karualona were discussed by Dumont and Silva-Briano (2000). A description of the parthenogenetic female and a brief diagnosis of the male

A

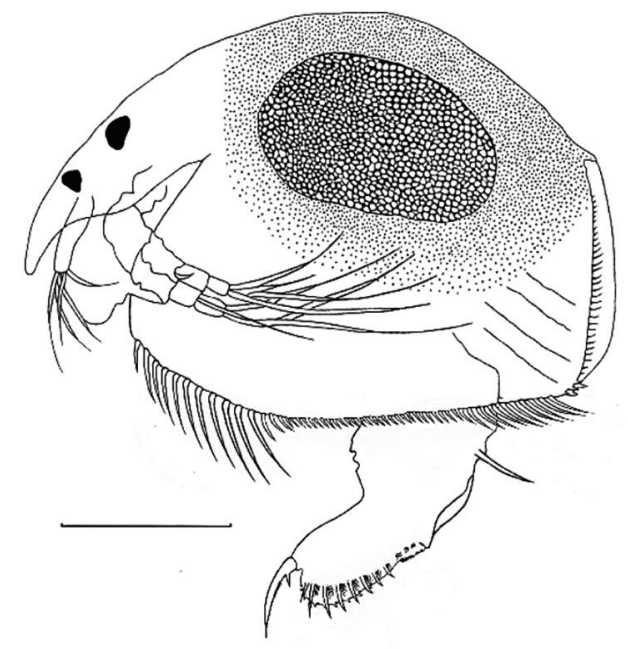

C

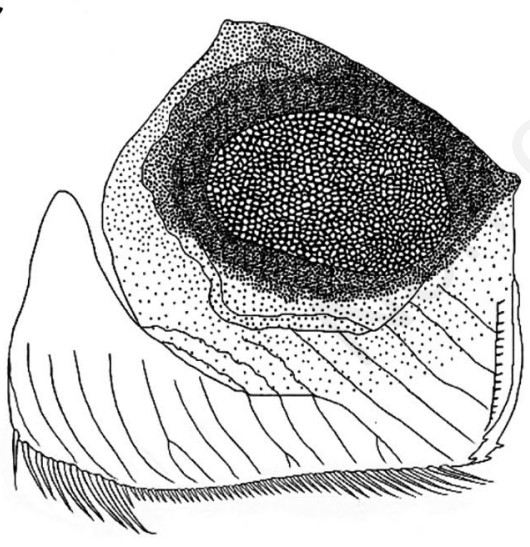

E

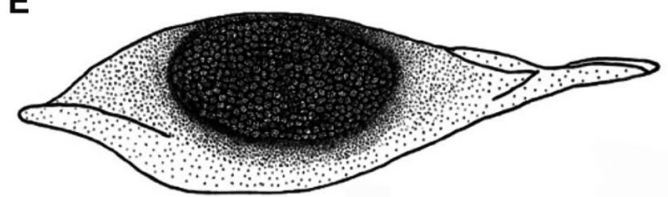

based on illustrations by Sars were provided by Sinev and Hollweldel (2005). Drawings of the male were presented by Van Damme and Dumont (2010).

The length and height of the males were similar to the dimensions of the first and second instars. The females in
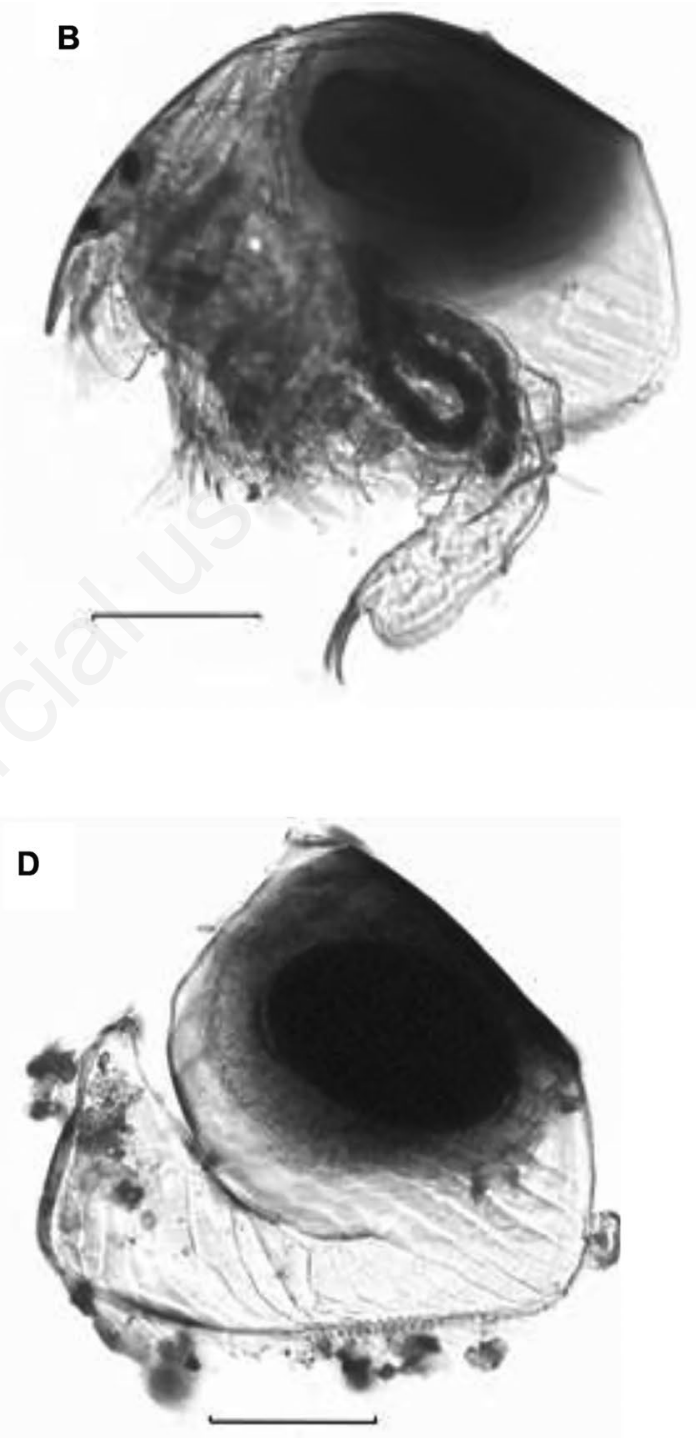

$\mathbf{F}$

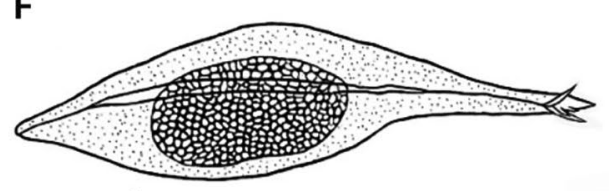

Fig. 2. Karualona muelleri. A,B) ephippial female; C,D) lateral resting egg; E,F) dorsal and ventral resting egg. Scale bar: $100 \mu \mathrm{m}$. 
the same instar were about 1.3 times greater in length and height than the males. The male antennule was slightly larger than that in the female. The length of the male postabdomen was similar to that of the female, but narrower distally, and thus it appeared longer. The anal teeth found on the post-abdomen, i.e. 6-8 in the female, were not present in the male, but instead the spicules were not arranged in groups along the whole post-anal margin. The male basal claw was smaller compared with that in the first instar. On average, the adult female post-abdominal claw was 2.3 times larger than the male post-abdominal claw.

The specimens from Serra da Canastra possessed 26 to 55 setae, including the adults, first instars, and second instars. The setae on the anterior region increased gradually in length where this increase was interrupted by a sequence of short setae (four times smaller than those before), before increasing in length again toward the denticles in the carapace postero-ventral angle. The intermediate and posterior setae varied in number according to the developmental stage, where the younger individuals tended to have a low number of small setae in the intermediary region. The long and short setae differed little in the males, where the long ones did not exceed twice the length of the short ones. $K$. muelleri from Serra da Canastra had one to four denticles on the carapace postero-ventral angle and this number could vary on each valve.
Many of the characteristics that differed between the first instar and primipara increased in size with bodily growth during development. However, the distance between the eye and ocellus appeared to reduce during development, except in the male, which retained the juvenile characteristics (Tab. 1). The characteristics that did not increase in dimension between the first instar and adult comprised: the basal spine length on the basal claws, length of the post-abdomen, claw base width, and antennule length. The antennule was slightly larger in the male than the other forms (Tab. 1).

The ephippial female (Fig. 2 A,B) had very similar morphometric characteristics to the parthenogenetic female, where they were distinguished based mainly on the dorsal carapace color. The light brown pigmentation appeared before the definition of the group of cells that developed into an embryo, where the pigmentation became increasingly darker during resting egg development. At the end of gestation, a very dark brown color was visible in the dorsal region of the mother, and this color was clearer toward the carapace border.

The resting egg (Fig. 2 C-F) detached from the female during molting and a large part of the maternal carapace was retained. The resting egg was elongated in the ventral position (Fig. 2F) with sharpened distal extremities, and the two extremities were longitudinally linked by a line

Tab. 1. Range of variation in body size and number of morphological structures of the K. muelleri in different development phases and genre.

\begin{tabular}{lccccc} 
& First instar & Second instar & \multicolumn{2}{c}{ Female } & Male \\
& & & Parthenogenetic & Ephippial \\
Maximum length $(\mu \mathrm{m})$ & $203-241$ & $260-344$ & $357-405$ & $338-375$ & $277-321$ \\
\hline Maximum height $(\mu \mathrm{m})$ & $130-162$ & $117-249$ & $216-284$ & $232-253$ & $179-191$ \\
\hline Carapace distal height $(\mu \mathrm{m})$ & $75-88$ & $83-130$ & $116-143$ & $124-138$ & $106-113$ \\
\hline Antennule height $(\mu \mathrm{m})$ & $41-48$ & $39-45$ & $34-47$ & $44-46$ & $47-60$ \\
\hline Antenunule length $(\mu \mathrm{m})$ & $10-12$ & $9-15$ & $11-17$ & $12-15$ & $15-17$ \\
\hline Labrum keel height $(\mu \mathrm{m})$ & $44-57$ & $42-68$ & $56-79$ & $53-62$ & $50-66$ \\
\hline Distance eye/ocellus $(\mu \mathrm{m})$ & $36-44$ & $28-40$ & $32-38$ & $24-36$ & $35-41$ \\
\hline Post-abdomen length $(\mu \mathrm{m})$ & $71-85$ & $82-126$ & $120-148$ & $94-133$ & $118-123$ \\
\hline Post-abdomen width $(\mu \mathrm{m})$ & $34-37$ & $38-52$ & $52-61$ & $50-54$ & $39-41$ \\
\hline Postabdominal claw length $(\mu \mathrm{m})$ & $28-32$ & $31-49$ & $41-49$ & $39-44$ & $18-21$ \\
\hline Postabdominal claw base width $(\mu \mathrm{m})$ & $5-7$ & $5-9$ & $5-10$ & $7-8$ & $8-8$ \\
\hline Length basal spine $(\mu \mathrm{m})$ & $3-4$ & $4-5$ & $4-5$ & 4 & 4 \\
\hline Post-abdomen marginal denticles $($ number) & $7-9$ & $7-9$ & $7-9$ & $7-10$ & 0 \\
\hline Setae of postabdominal lateral fascicle (number) & $7-8$ & $7-9$ & $7-9$ & $7-10$ & $5-8$ \\
\hline Setae of the carapace ventral margin (number) & $26-37$ & $29-42$ & $41-50$ & $43-55$ & $30-33$ \\
\hline \hline
\end{tabular}


formed by valve margins, with a thin opening between them. The marginal setae might not be preserved, but when the carapace did not break, the postero-ventral spines were visible in both the lateral and ventral positions. The embryo was also elongated, bulging, and enveloped, with two embryonic membranes protected by the carapace valves left after the molt (Shan, 1969; Fryer, 1996a). The internal layer wrapped the embryo under the pigmented part of the external layer (carapace). In the dorsal view, the internal layer was barely visible due to the dark carapace pigmentation, which also hindered the visualization of the head pores.

The measurements obtained for the resting egg embryos (a very dense cellular mass with an oval shape) did not differ greatly from the measurements for the parthenogenetic eggs (Tab. 1), but the enveloped structure was not present in the latter. The presence of a break in the maternal carapace extending from the ventral region toward the posterior region was recurrent. When this occurred, only part of the carapace surrounding the embryo region remained, which was preserved as parallel longitudinal lines as a characteristic of the genus.

The results obtained by MANOVA-CV based on eight morphometric variables indicated differences among the life stages observed, including males and parthenogenetic and ephippial females (Wilks' $\lambda=0.01655 ; \mathrm{F}=6.923$; $\mathrm{P}<0.001)$. The results were supported by canonical variable analysis and they indicated segregation among some of the groups analyzed (Fig. 3). The comparative observations indicated no significant differences between the second instar and females (both parthenogenetic and ephippial) (Tab. 2 and Fig. 3). However, the characteristics of the first instar differed significantly compared with the other forms, although these differences were not significant between the first instar and males (Tab. 2) because these two groups shared several similar morphometric characteristics (Tab. 1). Our results may have been affected by the lower number of samples (male $\mathrm{n}=3$ ) considering the consistent differences in the morphometric features of the postabdomen, such as the basal claw length, claw base width, and post-abdomen length. These combined features could separate the two groups in the graphical representation of the multivariate space (Fig. 3).

\section{Population attributes}

The resting eggs that originated from the populations analyzed in this study hatched between the $4^{\text {th }}$ and $11^{\text {th }}$ incubation days at temperatures between $23^{\circ} \mathrm{C}$ and $26^{\circ} \mathrm{C}$ (average: $25^{\circ} \mathrm{C}$ ). The females produced parthenogenetic eggs after $24 \mathrm{~h}$ of life. Each female with a gamogenetic origin produced only one egg per brood, whereas females with a parthenogenetic origin produced one or two eggs per brood with a duration of two or three days, and with a pause for one day before the appearance of the new embryo.

The greatest longevity was recorded for a female with a parthenogenetic origin at 17 days. However, $47 \%$ of the individuals survived for a maximum of five days and $53 \%$ survived more than eight days. Among the females with a gamogenetic origin, the greatest lifespan was 16 days

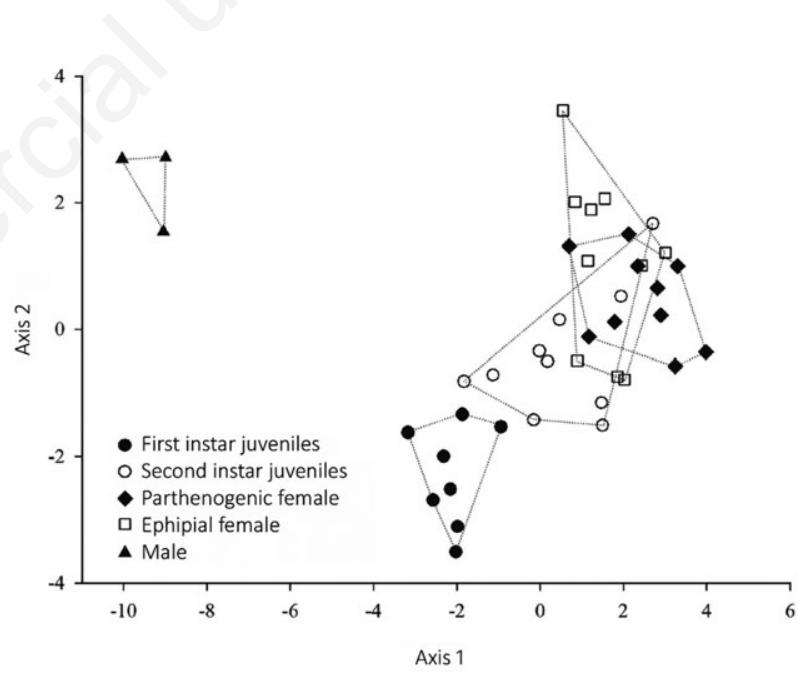

Fig. 3. Multivariate canonical analysis based on eight morphometric characteristics clustered among first instar juveniles, second instar juveniles, parthenogenetic females, ephippial females, and males.

Tab. 2. Significance values (P) from Hotelling test to MANOVA-CV test using eight morphometric variables compared among first instar, second instar and adult K. muelleri: male ( $\overbrace{}^{\Uparrow})$, parthenogenetic female ( + PA) and ephippial female ( + EP).

\begin{tabular}{lcccc} 
& First instar & Second instar & P PA EP \\
First instar & & & & \\
\hline Second instar & 0.0331 & & & \\
\hline q PA & 0.0016 & $0.1041(\mathrm{~ns})$ & $0.2926(\mathrm{~ns})$ & \\
\hline q EP & 0.0028 & $0.1401(\mathrm{~ns})$ & 0.0100 & 0.0131
\end{tabular}


and $62 \%$ survived between eight and 10 days (Fig. 4). Regardless of their parthenogenetic and gamogenetic origins, $50 \%$ of the deaths that occurred in the first days of life were related to molting and first reproduction. The longest reproductive range was 15 days.

The average population growth intrinsic rate $(r)$ was $r$ $=0.18$. The highest $r$ value was observed in population 2 , but all of the individuals were dead on the $18^{\text {th }}$ day of cultivation in this population. The lowest $r$ value was recorded for population 6 , where sexual reproduction did not occur (Tab. 3 and Fig. 5). The birth rate varied between 0.38 and 0.51 and the death rate between 0.23 and 0.28 .

Ephippial females represented $0 \%$ to $10 \%$ of the populations and they appeared two or three days after male emergence (zero to two individuals per population). The appearances of males, ephippial females, and resting eggs occurred near the changes in the exponential adjustment of the population density between the $23^{\text {rd }}$ and $30^{\text {th }}$ cultivation days, with a population between 92 and 135 individuals (Fig. 5) in a volume of $50 \mathrm{~mL}$, which corresponded to an approximate density of 2000 individuals $\mathrm{L}^{-1}$.

\section{DISCUSSION}

The species Karualona muelleri was first described by Richard (1897) more than a century ago. However, a highly detailed taxonomic description is only available for the parthenogenetic female according to Sinev and Hollwedel (2005), who described the limbs in addition to the external morphology. In the present study, the cultivation of this species in the laboratory allowed us to investigate the population dynamics as well as to observe the intraspecific morphometric variations among the life stages and sexual dimorphism.

The characteristics related to body size, specific structure size, and setae number on the carapace ventral margin increased with the age of the individual. However, some characteristics remained constant in this species and they are useful for identification, whereas others might not follow an expected pattern with increases proportional to the body size.

According to Sinev and Hollowedel (2005), 40 to 45 setae of different sizes are present on the ventral margin of the adult female carapace comprising 11 to 14 long setae, followed by 10 to 15 very short setae, and the setae length then increases distally, where the number of denticles on the postero-ventral angle of the carapace varies between three and five. We recorded a smaller number of denticles on the postero-ventral angle of the carapace and a larger range of variation in the number of setae in all of the phases analyzed, but with a differentiated pattern in the males.

The basal spine size in K. muelleri appears to be a fixed characteristic of this species during the different developmental phases in both females and males. The number of post-abdomen marginal denticles varied little (7-10) during the developmental phases, except the males had short setae inserted on the post-abdomen margin instead of spines.

The sexual dimorphism in Chydoridae males is characterized by modifications in the structures related to

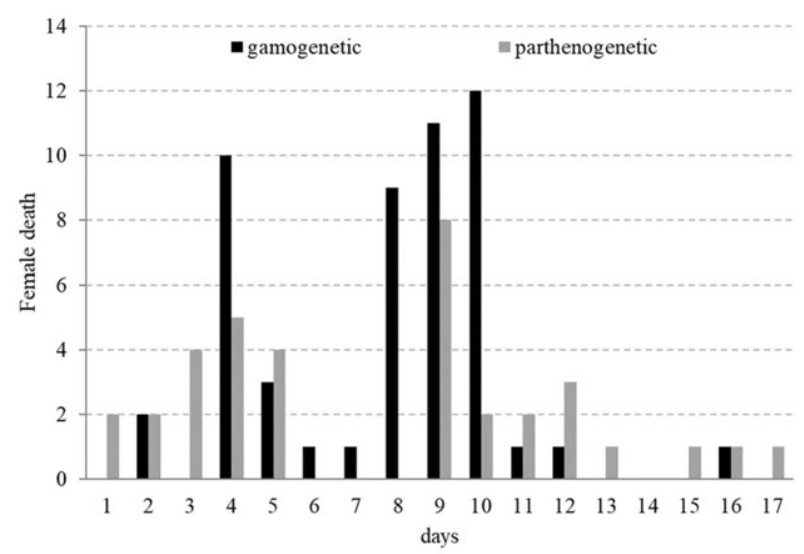

Fig. 4. Mortality in each female group: gamogenetic and parthenogenetic.

Tab. 3. Population attributes estimated in the experiments: $r$, population growth intrinsic rate; $b$, birth rate; $d$, death rate.

\begin{tabular}{lcccccc} 
& Density in the beginning of the sexual reproduction & $r$ & $b$ & $d$ & 0.445 & 0.232 \\
\hline Population 1 & 135 & $*$ & 0.213 & 0.240 & 0.510 & 0.270 \\
\hline Population 2 & 92 & 0.188 & 0.416 & 0.227 & 0.241 \\
\hline Population 3 & 106 & 0.155 & 0.397 & 0.228 \\
\hline Population 4 & 95 & 0.152 & 0.380 & 0.428 & 0.282 & 0.147 \\
\hline Population 5 & $*$ & & 0.428 & \\
\hline Population 6 & & &
\end{tabular}

*No sexual reproduction. 

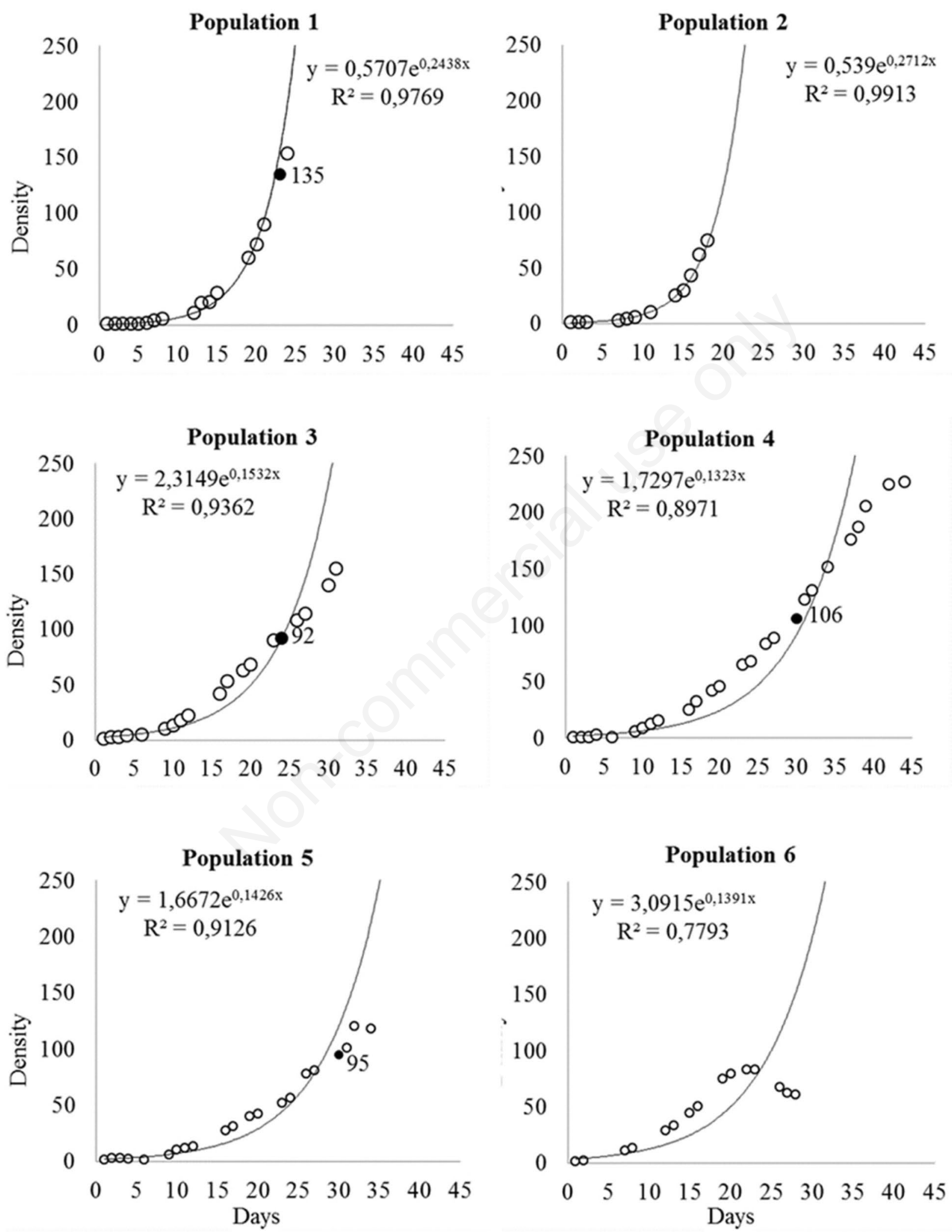

Fig. 5. Population density, exponential fitness of the population growth, and appearance of males (highlighted by •). 
coupling, such as the presence of a copulatory hook, modification of the inner distal lobe of limb I, including the presence of copulatory brush setae and male setae (which are absent in the female), a larger number of aestetascs in the antennule with the possible presence of lateral male setae, the post-abdomen narrowing distally with a genital opening in the post-abdomen visible and the presence of gonopores or a penis-like projection, and the marginal denticles (present on the female post-abdomen) are replaced by a group of setules (Smirnov 1996; Sinev, 2000; Kotov, 2009; Sinev and Sanoamuang, 2011).

The $K$. muelleri male has a very small basal claw even when compared with the first instar, while its postabdomen width is similar to that of the first instar and its length is similar to that of the adult female (Tab. 1). In addition, a slight distal narrowing gives an elongated appearance to the male post-abdomen. These characteristics are important for distinguishing the first instar and males because they also share several similarities according to the results obtained by morphometric analysis (Tab. 2), thereby allowing males to go unnoticed in populations. Sinev (2000) and Sinev and Sanoamuang (2011) studied the post-embryonal development of Alona affinis (Leydig, 1860) and Oxyurella singalensis (Daday, 1898), respectively, and they also observed large similarities between the females and juvenile males, but mainly in the first stage.

Our analysis of the morphometric characteristics did not detect differences between the parthenogenetic and ephippial females in terms of the characters considered according to MANOVA-CV (Tab. 2 and Fig. 3). Smirnov (1971) and Sinev and Shiel (2012) also found no differences between parthenogenetic and ephippial females in terms of the thoracic appendices, head, and post-abdomen.

The description given by Sars (1901) is the only record of $K$. muelleri ephippial females, which were referred to at that time as Alonella karua King, 1853: "...were easily recognizable even with the naked eye, by the dark brownish hue and jerky movements. In females carrying resting ova (one such ovum only, as usual, was found in each individual) the upper part of the carapace often assumed a very dark, almost black colour."

The production of resting eggs is an important characteristic of several Cladocera species. The egg bank acts as an ecological and evolutionary reserve (Fryer, 1996b; Brendock and DeMeester, 2003) to ensure the persistence of populations in the environment, even under extreme conditions. Despite the importance of resting eggs for the dispersion of cladoceran populations, the identification of the eggs is still difficult. Vandekerkhove et al. (2004) noted the ecological importance of identifying resting eggs and stated that drawings or images for identification are available for approximately one-quarter of the European species. This information is even scarcer for South American species and only included in taxonomic studies, thereby limiting access to this information (Paggi, 1996, 1999; Elmoor-Loureiro, 2014).

In this study, we characterized the resting egg in $K$. muelleri in order to facilitate its identification to the genus level. In addition to the morphometric characteristics of the embryo, parallel lines are also present on the carapace sculpture and punctiform ornamentation on the ephippia surface, which are important characteristics. The same pattern was observed previously in the Karualona iberica Alonso and Pretus, 1989 ephippial female. However, some important characteristics such as the anastomosis on the valve sculpture as well as the row of carapace marginal setae and denticles on the posteroventral portion of valve can be lost while residing in the sediment, thereby hindering specific egg identification. The fissure on the mother carapace recorded by Alonso and Pretus (1989) and in the present study (Fig. 2 C,D) demonstrate the fragility of these structures as a consequence of friction from sediment and burial pressure. Thus, placing the egg in hatching conditions is the most reliable method for identification in addition to providing important life history information.

Life history information for $K$. muelleri is still lacking and only brief descriptions are available. In particular, Sinev and Hollwedel (2005) characterized the temperature $\left(25^{\circ} \mathrm{C}\right)$ and $\mathrm{pH}$ (alkaline to slightly acid) of the sites where samples were collected. Van Damme and Dumont (2010) described the rapid movements of the species and a low tolerance of sudden temperature drops by the parthenogenetic females. Recent studies (ElmoorLoureiro, 2007; Van Damme and Dumont, 2010; Santos-Wisniewski et al., 2011; Sousa and ElmoorLoureiro, 2012; Maia-Barbosa et al., 2014) suggest that this species is found mainly in lentic systems.

According to our results and previous studies, $K$. muelleri can occur in environments with an alkaline to acid $\mathrm{pH}$, and it can tolerate conditions with a relatively low dissolved oxygen content because it was recorded in a shallow lake with a dissolved oxygen content of 3.98 $\mathrm{mg} \mathrm{L}^{-1}$. The intolerance of sudden drops in temperature $\left(28^{\circ} \mathrm{C}\right.$ to $\left.20^{\circ} \mathrm{C}\right)$ and the high mortality observed by Van Damme and Dumont (2010) could be a local population characteristic because they observed individuals that originated from an environment with more stable temperatures, located at low latitudes and at sea level. Our results showed that a drop in temperature of $4^{\circ} \mathrm{C}$ over 24 $\mathrm{h}$ and gradual variations between $23^{\circ} \mathrm{C}$ and $32^{\circ} \mathrm{C}$ did not compromise the growth $(r)$ of the population from Serra da Canastra, where the temperature may vary greatly between the day and night.

The $r$ values obtained in this study indicated population growth between $15 \%$ to $24 \%$ per day, where 
the age of just one day for the first brood is relatively early compared with the revised data given by Castilho et al. (2015) who reported that the age for the first brood was between 2.37 (Chydorus pubescens Sars, 1901) and 5.73 days (Chydorus dentifer Daday, 1905). Ovalona kaingang (Sousa, Elmoor-Loureiro and Santos, 2015) was identified as Coronatella rectangula (Sars, 1861) by Viti et al. (2013) and as Flavalona margipluma (Sousa, Santos, Güntzel, Diniz, Melo Junior and Elmoor-Loureiro, 2015) by Sousa and Elmoor-Loureiro (2019) (Alona iheringula in Santos-Silva et al. 2014), and it had the first brood between 2.48 and 2.24 days.

The average egg development time of 2.50 days for $K$. muelleri is within the range of variation found in the species cited by Castilho et al. (2015). However, the fecundity of $K$. muelleri is lower compared with that of all the species reported previously.

To some extent, a small brood can be balanced by rapid development characterized by small size with only a few juvenile instars (Bottrel, 1975). Chydoridae parthenogenetic females usually pass through two immature instars before reproduction commences (Frey, 1987), although with some exceptions, excluding the "pseudomolt" indicated by Kotov (1997). The number of molts is considered a major development characteristic with phylogenetic importance, thereby supporting the possible close relationship between the Chydoridae and Bosminiidae families based on the similarity in the number of juvenile stages (two juvenile instars for males).

Small species such as $K$. muelleri tend to have less juvenile instars than large species. A constant number of juvenile instars for a particular species in variable temperature conditions was found by Bottrel (1975), although a variable number of juvenile instars might occur in geographically isolated populations of the same species and according to the culture conditions used in experiments. In addition, Robertson (1988) verified Chydoridae primipara in the third and fourth instars, whereas a lower number of instars was related to temperature increases.

K. muelleri primipara in a third instar was observed in this study, but the number of molts was not quantified for each specimen and given that the second instar is twice as large as the first, it is possible that a third juvenile instar could occur under various temperature conditions. However, Murugan and Job (1982) observed a distinct growth rate between juvenile instars, where the highest growth rate occurred between the first and second instars.

Several studies have reported two juvenile instars in small Chydoridae, including Alona iheringula (Sinev, 2001), Chydorus pubescens (Santos-Wisniewski et al., 2006) Alona salina Alonso, 1996 (Sinev et al., 2009), Alona yara and Acroperus tupinamba (Sinev and Elmoor-
Loureiro, 2010), Coronatella rectangula (Viti et al., 2013). Maturation at an early age may utilize energy better to ensure early survival and successful reproduction but at the expense of a long lifespan (Lynch, 1980b).

The greatest longevity observed in our experiment was 17 days and most of the individuals survived between eight and 10 days. These values are lower compared with most of the species recorded by Castilho et al. (2015) and only similar to the longevity determined for Acroperus harpae Baird, 1843 (probably Acroperus tupinamba; Sinev and Elmoor-Loureiro, 2010) at 9.79 days and for Chydorus dentifer at 11.39 days (both cultivated at $25^{\circ} \mathrm{C}$ ). Moreover, mortality during molting and first reproduction can hinder population growth.

The differences in the attributes described above may be related to the adaptation of the species to the cultivation temperature because most of the experiments were performed at constant temperature or with less variation than that applied in our study. The populations of the genus Chydorus Leach, 1816 exhibit marked variations in their reproductive characteristics when the temperature varies by $5^{\circ} \mathrm{C}$ (Castilho et al., 2015). Temperature variations during experiments may lead to metabolic alterations, thereby reducing the reproductive efficiency and longevity, and thus individuals may deviate from their optimum life history.

Lynch (1980b) reported several reasons (genetic, physiological, and morphological) why an optimum life history might never occur in real conditions, thereby indicating the importance of comparing the life histories of close species under different selection pressures. $K$. muelleri can exhibit better reproductive performance in more stable temperature conditions than those observed in this study. However, thermal stability is not a realistic condition in rock fields (Gionotti et al., 2013).

Tolerating temperature variations in the active phase is not sufficient for long-term permanence in temporary rock field lakes. In these intermittent systems, the populations must produce forms that can resist drought and even fire because these systems may be subject to both natural and anthropic fires during the dry seasons. In a study of resistant forms, Radzikowski (2013) reported the capacity of the embryo to survive temperatures above $100^{\circ} \mathrm{C}$, which may indicate tolerance of fire events. However, it is possible that the resting eggs that form part of the active fauna after a fire event could arrive from other water bodies via passive dispersal, such as by the wind or transport by animals, i.e. attachment to the external surfaces or by passing through the digestive tract of a dispersion vector (Figuerola and Green, 2002; Charambidou et al., 2003; Frisch et al., 2007; Vaschoenwinkel et al., 2008, 2011).

The slowdown in population growth after the appearance of the male in this phase suggests that 
overpopulation acts as a stimulus to sexual reproduction and the generation of resting eggs, which was possibly related to intraspecific competition or unfavorable chemical conditions in our experiment. Overpopulation is well known to stimulate sexual reproduction in Anomopoda, but its effect may vary among species.

Kleiven et al. (1992) demonstrated that sexual reproduction in Daphnia magna Straus, 1820 was associated with three stimuli comprising the photoperiod, food limitation, and chemically mediated crowding. The stimulus for ephippia production did not occur without the photoperiod and males were abundant. Zadereev et al. (2003) found that the change in the reproduction mode was determined by food availability and the combined effect of food availability and metabolic by-products in Moina macrocopa (Straus 1820), where the population reached a maximum in both cases, before declining and stabilizing, with ephippia and males comprising $20 \%$ and $30 \%$ of the population, respectively. In our study, males represented $0 \%$ to $2 \%$ of the population and ephippia were produced shortly after their emergence, but stability was not observed even after the slowdown of population growth.

\section{CONCLUSIONS}

In this study, we showed that many of the morphometric structures increased in size during development, except in the male. The length of the basal spine was the least variable among the characteristics measured. The expected similarity between the male and juvenile phases was observed, but the morphometric analyses only confirmed the similarities between the male and first instar. However, a long post-abdomen and shorter basal claw were determined as clear morphometric differences between males and first instar females. Parthenogenetic and ephippial females were differentiated more clearly based on the carapace color and egg appearance than the other morphometric structures analyzed in this study.

Population crowding was determined as a cause of the induction of sexual reproduction by $K$. muelleri between the third and fourth weeks. This trend appeared to be interrupted by the emergence of males but there was no apparent influence due to the renewal of the culture medium. However, the specific causes of the slowdown of reproduction require future investigation.

\section{ACKNOWLEDGMENTS}

CNPq - Process no. 563318/2010-4 and Fundação de Amparo à Pesquisa do Estado de São Paulo FAPESP Process no. 2010/52318-6.

\section{REFERENCES}

Alonso MJ, Pretus L, 1989. Alona iberica, New species: First Evidence of Noncosmopolitanism within the A. karua complex (Cladocera: Chydoridae). J. Crustacean Biol. 9:453-476.

Bottrell HH, 1975. Generation time, length of life, instar duration and frequency of moulting, and their relationship to temperature in eight species of Cladocera from River Thames, Reading. Oecologia 19:129-140.

Brendock L, De Meester L, 2003. Egg banks in freshwater zooplankton: evolutionary and ecological archives in the sediment. Hydrobiologia 491:65-84.

Castilho MCA, Wisniewski MJS, Abreu CB, Orlando TC, 2015. Life history and DNA barcode of Oxyurella longicaudis (Birgei, 1910) (Cladocera, Anomopoda, Chydoridae). Zool. Stud. 54:1-7.

Charalambidou I, Ketelaars HAM, Santamaría L, 2003. Endozoochory by ducks: influence of developmental stage of Bythotrephes diapause eggs on dispersal probability. Diver. Distrib. 9:367-374.

Dumont HJ, Silva-Briano M, 2000. Karualona n. gen. (Anomopoda: Chydoridae), with a description of two new species, and a key to all known species. Hydrobiologia 435:61-82.

Edmondson WT, Winberg GG, 1971. A manual on methods for the assessment of secondary productivity in fresh waters. IBP Handbook 17. Blackwell Scientific Publications, Oxford: $357 \mathrm{pp}$.

Elmoor-Loureiro LMA, 2007. Phytophilous cladocerans (Crustacea, Anamopoda, Ctenopoda) from Paranã River Valley, Goiás, Brazil. Rev. Bras. Zool. 24:344-352.

Elmoor-Loureiro LMA, 2014. Ephemeroporus quasimodo sp. nov. (Crustacea: Cladocera: Chydoridae), a new species from the Brazilian Cerrado. Zootaxa 3821:88-100.

Elmoor-Loureiro LMA, 2017. [Cladóceros do Brasil: Famílias Chydoridae e Eurycercidae].[Website in Portuguese]. Available from: https://cladocera.wordpress.com.

Figuerola J, Green AJ, 2002. Dispersal of aquatic organisms by waterbirds: a review of past research and priorities for future studies. Freshwater Biol. 47:483-494.

Frisch D, Green AJ, Figuerola J, 2007. High dispersal capacity of a broad spectrum of aquatic invertebrates via waterbirds. Aquat. Sci. 69:568-574.

Frey DG, 1987. The taxonomy and biogeography of the Cladocera. Hydrobiologia 145:5-17.

Fryer G, 1996a. Diapause, a potent force in the evolution of freshwater crustaceans. Hydrobiologia 320:1-14.

Fryer G, 1996b. The carapace of the Branchiopod Crustacea. Philos. T. R. Soc. Lond. 351:1703-1712.

Gianotti ARC, Souza MJH., Machado ELM, Pereira IM, Vieira AD, Magalhães MR, 2013. [Análise microclimática em duas fitofisionomias do Cerrado no Alto Vale do Jequitinhonha, Minas Gerais].[Article in Portuguese]. Rev. Bras. Meteorol. 28:146-256.

Gotteli NJ, 2008. A primer of ecology. Sinauer Associates, Sunderland: $291 \mathrm{pp}$.

Hammer Ø, Harper DAT, Ryan PD, 2001. Past: paleontological statistics software package for education and data analysis. Palaeontol. Electron. 4:1-9. 
Kleiven OT, Larsson P, Hobæk A. 1992. Sexual reproduction in Daphnia magan requires tree stimuli. Oikos 65:197-206.

Kotov AA, 1997. A special moult after the release of the embryo from the brood pouch of Anomopoda (Branchiopoda, Crustacea): a return to an old question. Hydrobiologia 354:83-87.

Kotov AA, 2009. A revision of Leydigia Kurz, 1875 (Anomopoda, Cladocera, Branchiopoda), and subgeneric differentiation within the genus. Zootaxa 2082:1-68.

Kotov AA, Saeheng S, Maiphae S, Van Damme K, 2013. Study of the embryogenesis of Dunhevedia crassa King, 1853 (Cladocera: Chydoridae) and a comparison of embryonic instar durations in different cladocerans. J. Limnol. 72:e47. Doi: 10.4081/jlimnol.2013.e47.

Lynch, M, 1980a. Predation, enrichment and the evolution of cladoceran life histories: A theoretical approach, p. 367-377. In: W.C. Kerfoot (ed.), Evolution and ecology of zooplankton communities. University Press of New England.

Lynch M, 1980b. The Evolution of Cladocera live histories. Q. Rev. Biol. 55: 3-42.

Maia-Barbosa PM, Menendez RM, Pujoni D, Brito SL, Aoki A, Barbosa FAR, 2014. Zooplankton (Copepoda, Rotifera, Cladocera and Protozoa: Amoeba Testacea) from natural lakes of the middle Rio Doce basin, Minas Gerais, Brazil. Biota Neotrop. 14:1-20.

Martínez-Jerónimo F, Gómez-Díaz P, 2011. Reproductive biology and life cycle of Leydigia louisi mexicana (Anomopoda, Chydoridae), a rare species from freshwater littoral environments. Crustaceana 84:187-201.

Murugan N, Job SV, 1982. Laboratory studies on the life cycle of Leydigia acanthocercoides Fisher (1854) (Cladocera: Chydoridae). Hydrobiologia 89:9-16.

Nevalainen L, Luoto TP, 2013. Sedimentary chydorid (Cladocera) ephippia in relation to lake ecological quality in the Austrian Alps. J. Limnol. 72:e5. Doi: 10.4081/jlimnol.2013.e5.

Paggi JC, 1996. Daphnia (Ctenodaphnia) menucoensis (Anomopoda; Daphniidae): a new species from athalassic saline waters in Argentina. Hydrobiologia 319:137-147

Paggi JC, 1999. Status and phylogenetic relationships of Daphnia sarsi Daday, 1902 (Crustacea: Anomopoda). Hydrobiologia 403:27-37.

Paloheimo, JE, 1974. Calculation of instantaneous birth rate. Limnol. Oceanogr. 19:692-694.

Radzikowski J, 2013. Resistance of dormant stages of planktonic invertebrates to adverse environmental conditions. J. Plankton Res. 35:707-723.

Richard J, 1897. [Entomostraces de l'Amérique du Sud, recueillis par M.M.U. Deiters, H. von Iheringi, G.W. Müller et C.O. Poppe].[Article in French]. Mem. Soc. Zool. France 10:203-301.

Robertson AL, 1988. Life histories of some species of Chydoridae (Cladocera: Crustacea). Freshwater Biol. 20:7584.

Santos-Wisniewski MJ, Rocha O, Matsumura-Tundisi T, 2006. Aspects of the life cycle of Chydorus pubescens Sars, 1901(Cladocera, Chydoridae). Acta Limnol. Bras. 18:305310.

Santos-Wisniewski MJ, Matsumura-Tundisi T, Negreiros NF,
Silva LC, Rocha O, 2011. O estado atual do conhecimento da diversidade dos Cladocera (Crustacea, Branchiopoda) nas águas doces do estado de Minas Gerais. Biota Neotrop. 11:287-301.

Sars GO, 1901. Contributions to the knowledge of the freshwater Entomostraca of South America as shown by artificial hatching from dried material. Part II. Copepoda-Ostracoda. Arch. Mathem. Naturvid. 24:1-52.

Shan RK, 1969. Life cycle of a chydorid cladoceran, Pleuroxus denticulatus Birge, Hydrobiologia 34:513-523.

Silva ES, Abreu CB, Orlando TC, Wisniewski C, Wisniewski MJS, 2014. Alona iheringula Sinev \& Kotov, 2004 (Crustacea, Anomopoda, Chydoridae, Aloninae): Life cycle and DNA barcode with implications for the taxonomy of the Aloninae subfamily. Plos One 9:e97050.

Sinev AY, 2000. Postembryonal development of male and abnormal sexual individuals of Alona affinis (Leydig, 1860) (Anomopoda, Chydoridae). Hydrobiologia 437:197-202.

Sinev AY, 2001. Redescription of Alona iheringi Sars, 1901 (Chydoridae, Anomopoda, Branchiopoda), a South American species related to A. rustica Scott, 1895. Hydrobiologia 464:113-119.

Sinev AY, Hollwedel W, 2005. Translocation of Alona muelleri Richard, 1897 into de genus Karualona Dummond \& SilvaBriano, 2000 (Brachiopoda: Anomopoda: Chydoridae). Arthropod. Sel. 14:93-101.

Sinev AY, Alonso, M, Shevelena, NG, 2009. New species of Alona from South-East Russia and Mongolia related to Alona sallina Alonso, 1996 (Cladocera: Anomopoda: Chydoridae). Zootaxa 2326:1-23.

Sinev AY, Elmoor-Loureiro LMA, 2010. Three new species of chydorid cladocerans of subfamily Aloninae (Branchipoda: Anomopoda: Chydoridae) from Brazil. Zootaxa 2390: -25.

Sinev AY, Sanoamuang, LO, 2011. Hormonal induction of males as a method for studying tropical cladocerans: description of males of four chydorid species (Cladocera: Anomopoda: Chydoridae). Zootaxa 2826:45-56.

Sinev AY, Shiel RJ, 2012. Extremalona timmsi gen. nov., sp. nov., a new cladoceran (Cladocera: Anomopoda: Chydoridae) from an acid saline lake in southwest Western Austral. J. Nat. Hist. 46:2845-2864.

Smirnov NN, 1971. Fauna of the USSR: Crustacea, Chydoridae. Keter Publishing House, Jerusalem: 531 pp.

Smirnov NN, 1996. Cladocera: the Chydorinae and Sayciinae (Chydoridae) of the word. Guides to the Identification of the Microinvertebrates of the Continental Waters of the Word. SPB Academic Publishing, Amsterdam: 197 pp.

Smirnov NN, 2017. Physiology of the Cladocera. Academic Press, London: $418 \mathrm{pp}$.

Sousa DFR, Elmoor-Loureiro LMA, 2012. How many species of cladocerans (Crustacea, Branchiopoda) are found in Brazilian Federal District? Acta Limnol. Bras. 24:351-362.

Sousa DFR, Elmoor-Loureiro LMA, 2019. Identification key for the Brazilian genera and species of Aloninae (Crustacea, Branchiopoda, Anomopoda, Chydoridae). Pap. Avulsos Zool. 59 e20195924.

Van Damme K, Dummont HJ, 2010. Cladocera of the Lençóis Marnhenses (NE - Brazil): faunal composition and reappraisal of Sars's Method. Braz. J. Biol. 70:755-779.

Van Damme K, Kotov AA, Dumont HJ, 2010. A checklist of 
names in Alona Baird 1843 (Crustacea: Cladocera: Chydoridae) and their current status: an analysis of the taxonomy of a lump genus. Zootaxa 2330:1-63.

Vandekerkhove J, Declerck S, Vanhove M, Brendonck L, Jeppesen E, Conde Porcuna JM \& De Meester L, 2004. Use of ephippial morphology to assess richness of anomopods: potentials and pitfalls. J. Limnol. 63:75-84. Doi: 10.4081/jlimnol.2004.s1.75.

Vanschoenwinkel B, Waterkey A, Vandecaetsbeek T, Pineau O, Grilla P, Brendonck L, 2008. Dispersal of freshwater invertebrates by large terrestrial mammals: a case study with wild boar (Sus scrofa) in Mediterranean wetland. Freshwater Biol. 53:2264-2273.

Vanschoenwinkel B, Waterkey A, Nhiwatiwa T, Pinceel T,
Spooren E, Geerta A, Clegg B, Brendonck L, 2011. Passive external transport of freshwater invertebrates by elephant and other mud-wallowing mammals in an African savannah habitat. Freshwater Biol. 56:1606-1619.

Vasconcelos MF, 2011. [O que são campos rupestres e campos de altitude nos topos de montanha do Leste do Brasil?].[Article in Portuguese]. Rev. Bras. Bot. 4:241-246.

Viti T, Wisniewski C, Orlando TC, Santos-Wisniewski MJ, 2013. Life history, biomass and production of Coronatella rectangula (Branchiopoda, Anomopoda, Chydoridae) from Minas Gerais. Iheringia Ser. Zool. 103:110-117.

Zadereev ES, Prokopkin IG, Gubanov VG, Gubanov MV, 2003. Individual-based model of the reproduction cycle of Moina macrocopa (Crustacea: Cladocera). Ecol. Model. 162:15-31. 